\title{
A STUDY ON THE DIFFERENTIATION BETWEEN ORANGE TREES DIRECTIONS ON THE CITRUS LEAFMINER, PHYLLOCNISTIS CITRELLA STAINTON (LEPIDOPTERA: GRACILLARIIDAE) AND THE COMMON PREDATORY SPECIES, IN QALUOBIYA GOVERNORATE
}

\author{
Bahy El-Din, I.A.; M.A.M. Ali and M.A.M. El-Khawas \\ Plant Protection Research Institute Bio. Control, Agriculture Research Center, Giza, Egypt
}

Keywords: Orange, Phyllocnistis citrella, Predators, Trees directions

\section{ABSTRACT}

Field studies were carried out to study the effect of the different four directions (East, West, North and South) and the middle of the orange trees on the occurrence of the citrus leafminer, Phyllocnistis citrella Staint. (Lepidoptera: Gracillariidae), attacking orange orchards during the period extended from the beginning of July, 2015 until the end of June 2016. Also, to determine the common predatory species occurred in navel orange orchards in Qaluobiya Governorate. The warmer months that have the highest temperature degrees and that months having the newly orange leaves, had the highest percentages of infestation by the pest. The obtained results revealed that, the South direction of the orange trees had the highest percentages of leaves damage by the citrus leafminer, $P$. citrella. Where, there were significant differences between the South direction (68.75\%), in comparing with those of the West direction $(64.42 \%)$, the North direction $(60.58 \%)$, the East direction $(54.58 \%)$ and the middle of the orange trees $(45.38 \%)$. So, it is recommended to firstly begin the Integrated Pest Management (IPM) programs against the pest in this direction and at the suitable time. Moreover, the importance of the natural role of the common predatory species recorded in the orange orchard is obviously shown and must be encouraged and developed. The highest total numbers of all recorded predatory species were during July, 2015 (47 individuals) and April, 2016 (35 individuals). The recorded predatory species were the highest in the South direction (70 individuals), in comparing with those of the North direction (54), the East direction (50), the West direction (37) and the middle of the orange trees (20). True spiders were recorded as the most predators (114 individuals), in orange orchard and also in the same time of pest occurrence. The animal predatory species (true spiders and predatory mites) were the highest in their numbers (167 individuals), in comparing to the insect predatory species: Chrysoperla carnea, Scymnus sp., Coccinella undecimpunctata, Orius sp. and Metasyrphus sp., of lower individuals numbers (64 individuals). In general, from this study, it is also recommended to use the different predatory species such as: Chrysoperla carnea, Scymnus sp., Coccinella undecimpunctata and Orius sp., for $P$. citrella control firstly from the South direction. Where, this pest control can be applied by mass rearing of these predators in the laboratory and releasing them in orange orchards against $P$. citrella or other related pests (such as the citrus aphids species and mealybugs). This approach is believed to be highly practical for use as one of the means of biological control with the frame work of suitable and safe IPM programs in citrus orchards in Egypt.

\section{INTRODUCTION}

Citrus growing areas in Egypt have been invaded by many insect pests including the citrus leafminer, Phyllocnistis citrella Staint. (Lepidoptera: Gracillariidae). This leafminer is considered as indirect pest affecting mostly the photosynthesis process through the reduction of the surface area (Knapp et al 1994). Pest larvae mine the adaxial and abaxial surfaces of newly formed leaves (Garcia-Mari et al 2002). The damaged leaves, curl and become chlorotic and necrotic, where this damage is less significant in mature trees. Heavy 
infestations can retard growth of nursery and newly planted trees and therefore reduce the yield of bearing trees (Penã et al 2000). After $P$. citrella finished feeding, other insect pests such as aphids and mealybugs often continue feeding on the damaged area (Michaud \& Grant, 2003). Furthermore, leaf wounds caused by pest larval feeding predisposes tree to infestation by the citrus bacterial canker Xanthomonas axonopodis (Hasse) (Graham et al 2004).

Extensive use of harmful chemical insecticides has resulted in environmental and economical problems; such as hazard effects against human, beneficial animals and insects (Rosell et al 2008). Besides, it was shown that, the effective chemical control of $P$. citrella is difficult because its larvae are protected by leaf cuticle and the pupae are protected by rolled leaf margins (Shaban \& Ohbayash, 2006). Therefore, classical biological control programs against this pest were continuously developed and encouraged in the Mediterranean area countries (Urbaneja et al 2004). Now, it is considered as the most economic and environmentally sound long term solution for managing $P$. citrella (Sanghyeob et al 2015). Also, Abo Abdalla (2015) stated that, biological control has showed promising option in $P$. citrella management.

Nevertheless, little information is known about the relationship existed between the occurrence of the leafminer $P$. citrella and the common predatory species found in the same time in citrus orchards. The well-adapted effective one of these predatory species can be laboratory mass reared and used in the field for the biological control purpose against this pest. So, the objective of this work was to study the effects of the four directions and the middle of the orange trees, on the occurrence of $P$. citrella population, moreover the occurrence of the common predatory species, during the period extended from the beginning of July, 2015 until the end of June, 2016, in Qaluobiya Governorate.

\section{MATEREAL AND METHODS}

\section{I- The occurrence of $\boldsymbol{P}$. citrella and predatory species}

Field studies were carried out in Qaluobiya Governorate, during the period extended from the beginning of July, 2015 until the end of June, 2016. An area of one fadden was chosen at Shebin ElKanater district, where it received the recommend- ed agricultural practices, except the chemical insecticides which were entirely avoided.

Monthly samples were conducted; each of these samples was represented by 20 randomly selected navel orange trees. Each orange tree was divided into 4 directions (East, West, North and South) and the middle., i.e., each monthly sample was 20 orange trees $\times 10$ young leaves for each of the 4 directions and also10 leaves from the middle $=1000$ monthly randomly young orange leaves. These leaves were placed into plastic bags (with a sheet of adsorbent paper to adsorb condensation). They were transported to the laboratory in the Biological Control Research Department, Agricultural Research Center (A.R.C.), where they were immediately examined under a binocular stereomicroscope.

At the same time, the common observed predatory species, found in the orange orchard were recorded and directly counted in the field. The total numbers of orange damaged leaves by the pest were recorded and the percentages of the leaves damage were calculated. Also, the total numbers of $P$. citrella mines occupied by alive pest larvae were counted and the percentages of mines that contain these pest larvae were estimated according to the following equations:

\section{$\%$ of leaves damage in each of the four direc- tions and the middle of the orange tree Total no. of damaged leaves

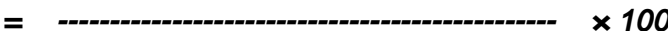 \\ Total no. of leaves of each monthly direction and middle sample (200 leaves) \\ $\%$ of mines containing alive pest larvae (= the degree of infestation) \\ Total no. of mines containing alive pest larvae

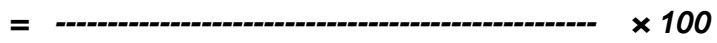

Total no. of pest mines in each monthly sample

\section{ח- Statistical analysis}

The obtained data were arranged in monthly tables and statistically analyzed, according to the procedures of Snedecor and Cochran (1980). The least significant differences (L.S.D.) test was run to compare the mean values at $1 \& 5 \%$ levels of probability, using SPSS computerized program version 18 and also Cohort 6 program. The monthly means of temperature $(\dot{\mathrm{c}})$, relative humidity $(\mathrm{R} . \mathrm{H} . \%)$ and wind $(\mathrm{km} / \mathrm{h})$, were obtained from the Meteorological Station of A.R.C. 


\section{RESULTS AND DISCUSSION}

\section{I- The percentages of $\boldsymbol{P}$. citrella damage}

Data presented in Table (1) which revealed the percentages of orange leaves damaged (for the East, West, North, South and the middle of the tree), during the period extended from the beginning of July, 2015 until the end of June, 2016. Obtained results showed that, the total numbers of damaged leaves/200 leaves were; $137.42 \pm 18.24$ (68.75\%), $128.83 \pm 16.71$ (64.42\%), $121.17 \pm 16.65$ $(60.58 \%), \quad 109.17 \pm 15.16(54.58 \%)$ and $90.76 \pm$ 13.07 (45.38\%) for the South, the West, the North, the East directions and the middle of the trees, respectively. These results indicated that, the South direction of the orange trees had the highest percentages of damage by $P$. citrella attack followed by the West, the North, the East directions and the middle of the trees. So, efforts could be firstly directed to control the pest in this direction. Also, the highest percentages of damage were recorded during December \& February (for the East direction), November \& May (for the West direction), December \& February (for the middle of the tree), November \& February (for the North direction) and November \& May (for the South direction). The pest damage was the highest during; November (the West, the North and the South directions), December.
The obtained results indicated that, $P$. citrella infestations to orange leaves were increased during spring and summer months and sharply declined in the period March-April. Similar results were also shown by Khalil et al (2001) in Egypt, who stated that, sever infestation with $P$. citrella was occurred during summer and early autumn. However, Diez et al (2006) and Charles et al (2007) showed that, $P$. citrella populations were the highest during the warmer months (AprilSeptember) and the lowest during the cooler months (November-March). While, Abo Abdalla (2015) indicated that, $P$. citrella infestation elevated during spring-summer and declined in the autumn. Where, the populations of $P$. citrella were shown to have a main peak by June \& a minor one by September (Abd El-Aziz, 1996) and also to have a peak during June (Charles et al 2007). Moreover, Chhetry et al (2012) demonstrated that, three peaks of $P$. citrella population were observed; the first peak was in April (spring flush), a small second peak was in July and the third one was in September (autumn flush).

Statistical analysis of the obtained data showed significant differences between the four tree directions and the middle of the orange tree, where, the L.S.D.0.05 was 0.013 (Table, 1 ).

Table 1. Damage of orange leaves caused by $P$. citrella, according to the four directions and the middle of the tree, during July, 2015 until June, 2016, at Qaluobiya Governorate

\begin{tabular}{|c|c|c|c|c|c|c|c|c|c|c|c|c|c|}
\hline \multirow[b]{2}{*}{ Months } & \multicolumn{2}{|c|}{ East } & \multicolumn{2}{|c|}{ West } & \multicolumn{2}{|c|}{ Middle } & \multicolumn{2}{|c|}{ North } & \multicolumn{2}{|c|}{ South } & \multicolumn{3}{|c|}{ Weather factors } \\
\hline & Total & $\%$ & Total & $\%$ & Total & $\%$ & Total & $\%$ & Total & $\%$ & $\begin{array}{l}\text { Temp. } \\
\left({ }^{\circ} \mathrm{C}\right)\end{array}$ & R.H.\% & $\begin{array}{l}\text { Wind } \\
\mathbf{k m} / \mathbf{h}\end{array}$ \\
\hline July,2015 & 123 & 1.35 & 139 & 69.50 & 93 & 46.50 & 127 & 63.50 & 143 & 71.50 & 28.74 & 52.10 & 8.00 \\
\hline Aug. & 112 & 56.00 & 124 & 62.00 & 82 & 41.00 & 121 & 60.50 & 138 & 69.00 & 31.10 & 52.13 & 10.45 \\
\hline Sept. & 125 & 62.50 & 168 & 84.00 & 109 & 54.00 & 147 & 73.50 & 176 & 88.00 & 29.93 & 49.50 & 10.37 \\
\hline Oct. & 129 & 64.50 & 151 & 75.50 & 120 & 60.00 & 143 & 71.50 & 166 & 83.00 & 25.94 & 58.29 & 9.23 \\
\hline Nov. & 138 & 69.00 & 172 & 86.00 & 116 & 58.00 & 164 & 82.00 & 181 & 90.00 & 20.50 & 64.10 & 7.13 \\
\hline Dec. & 160 & 80.00 & 148 & 74.00 & 126 & 63.00 & 133 & 66.50 & 161 & 80.00 & 15.71 & 64.10 & 10.26 \\
\hline Jan, 2016 & 135 & 67.50 & 144 & 72.00 & 113 & 56.00 & 150 & 75.00 & 158 & 79.00 & 13.71 & 58.39 & 15.19 \\
\hline Feb. & 144 & 72.00 & 172 & 86.00 & 128 & 64.00 & 167 & 83.50 & 174 & 87.00 & 18.34 & 52.79 & 13.52 \\
\hline Mar. & 0 & 0.00 & 0 & 0.00 & 0 & 0.00 & 0 & 0.00 & 0 & 0.00 & 21.19 & 45.65 & 13.81 \\
\hline Apr. & 2 & 1.00 & 1 & 0.50 & 0 & 0.00 & 3 & 1.5 & 11 & 5.50 & 25.80 & 43.40 & 16.53 \\
\hline May & 137 & 68.50 & 176 & 88.00 & 121 & 60.50 & 161 & 80.50 & 183 & 91.50 & 26.87 & 42.13 & 15.00 \\
\hline June & 105 & 52.50 & 151 & 75.50 & 80 & 40.50 & 138 & 69.00 & 158 & 79.00 & 30.53 & 44.67 & 17.71 \\
\hline $\begin{array}{l}\text { Mean } \\
\pm S D\end{array}$ & $\begin{array}{c}109.17 \pm \\
15.16 \\
\end{array}$ & 54.58 & $\begin{array}{c}128.83 \pm \\
16.71\end{array}$ & 64.42 & \begin{tabular}{|c|}
$90.67 \pm$ \\
13.07
\end{tabular} & 45.38 & $\begin{array}{c}121.17 \pm \\
16.65\end{array}$ & 60.58 & $\begin{array}{c}137.42 \pm \\
18.24\end{array}$ & 68.75 & $24.03^{\circ} \mathrm{C}$ & $52.27 \%$ & 12.27 \\
\hline $\begin{array}{c}\text { L. } \\
\text { S.D.0.05 }\end{array}$ & $\begin{array}{l}\text { Total } \mathrm{n} \\
\text { together } \\
\text { East } \times \mathrm{W} \\
\text { East } \times \mathrm{W} \\
\text { East } \times \mathrm{W}\end{array}$ & $\begin{array}{l}\text { lest } \times S \\
\text { lest } \times 1 \\
\text { lest } \times\end{array}$ & $\begin{array}{l}\text { of dama } \\
\text { outh \& } \\
\text { liddle } \\
\text { lorth }\end{array}$ & East $\times 1$ & es (fo & outh & directi & iddle & South & Midd & $\times$ Nor & South & $\begin{array}{l}0.004 \\
0.001 \\
0.008\end{array}$ \\
\hline
\end{tabular}




\section{II- The degree of $P$. citrella mines infestations}

The degree of $P$. citrella mines infestations (which were represented by the percentages of mines containing alive larvae during the period extended from the beginning of July, 2015 until the end of June, 2016, was recorded in Table (2). The highest percentages of mines infestations, were reported in the South direction $(20.68 \%)$ followed by the West $(16.57 \%)$, the North $(13.30 \%)$, the East $(12.27 \%)$ and finally the middle of the orange tree $(10.94 \%)$. Where, the mean total numbers of the pest larvae were; $36.00 \pm 15.34,26.33 \pm 8.71$, $19.52 \pm 7.25,15.83 \pm 5.28$ and $11.42 \pm 2.99$, respectively. As a result, the South direction of the orange trees may be recommended as the suitable direction to firstly begin any control programs before any other ones or the middle of the trees. According to Beattie and Smith (1993) only two mines in each orange leaf is enough to reduce the growth of the tree to less than five years. Besides, Penã and Duncan (1993) demonstrated that, the heavily infested leaves (> 4 mines per leaf) are frequently distorted and may abscise.

Table 2. Mean Phyllocnistis citrella mines and alive larvae/200 leaves, during July, 2015 until June, 2016, at Qaluobiya Governorate (for the four directions and the middle of the tree).

\begin{tabular}{|c|c|c|c|c|c|c|c|c|c|c|}
\hline \multirow[b]{2}{*}{ Months } & \multicolumn{2}{|c|}{ East } & \multicolumn{2}{|c|}{ West } & \multicolumn{2}{|c|}{ Middle } & \multicolumn{2}{|c|}{ North } & \multicolumn{2}{|c|}{ South } \\
\hline & $\begin{array}{l}\text { Total } \\
\text { no. of } \\
\text { mines }\end{array}$ & $\begin{array}{c}\% \\
\text { mines } \\
\text { that } \\
\text { contain } \\
\text { alive } \\
\text { pest } \\
\text { larvae }\end{array}$ & $\begin{array}{l}\text { Total } \\
\text { no. of } \\
\text { mines }\end{array}$ & $\begin{array}{c}\% \\
\text { mines } \\
\text { that } \\
\text { contain } \\
\text { alive } \\
\text { pest } \\
\text { larvae }\end{array}$ & $\begin{array}{l}\text { Total } \\
\text { no. of } \\
\text { mines }\end{array}$ & $\begin{array}{c}\% \\
\text { mines } \\
\text { that } \\
\text { contain } \\
\text { alive } \\
\text { pest } \\
\text { larvae }\end{array}$ & $\begin{array}{l}\text { Total } \\
\text { no. of } \\
\text { mines }\end{array}$ & $\begin{array}{c}\% \\
\text { mines } \\
\text { that } \\
\text { contain } \\
\text { alive pest } \\
\text { larvae }\end{array}$ & $\begin{array}{l}\text { Total } \\
\text { no. of } \\
\text { mines }\end{array}$ & $\begin{array}{l}\% \text { mines } \\
\text { that } \\
\text { contain } \\
\text { alive pest } \\
\text { larvae }\end{array}$ \\
\hline $\begin{array}{l}\text { July, } \\
2015\end{array}$ & 170 & $\begin{array}{l}8.82 \\
(15)^{\star}\end{array}$ & 196 & $9.69(19)$ & 137 & $9.49(13)$ & 189 & $14.82(28)$ & 203 & $9.85(20)$ \\
\hline Aug. & 117 & $0.85(1)$ & 169 & $3.55(6)$ & 103 & $4.85(5)$ & 146 & $3.43(5)$ & 184 & $4.35(8)$ \\
\hline Sept. & 203 & $3.45(7)$ & 234 & $2.99(7)$ & 134 & $1.49(2)$ & 225 & $2.67(6)$ & 239 & $5.02(12)$ \\
\hline Oct. & 135 & $3.70(5)$ & 164 & $\begin{array}{c}14.02 \\
(23) \\
\end{array}$ & 127 & $\begin{array}{c}11.81 \\
(15)\end{array}$ & 161 & $2.48(4)$ & 198 & $4.55(9)$ \\
\hline Nov. & 146 & $\begin{array}{c}26.71 \\
(39) \\
\end{array}$ & 179 & $\begin{array}{c}41.90 \\
(75)\end{array}$ & 118 & $\begin{array}{c}28.81 \\
(34) \\
\end{array}$ & 171 & $46.20(79)$ & 193 & $32.12(62)$ \\
\hline Dec. & 165 & $\begin{array}{c}16.36 \\
(27)\end{array}$ & 174 & $\begin{array}{c}17.82 \\
(31)\end{array}$ & 134 & $\begin{array}{c}11.94 \\
(16)\end{array}$ & 168 & $5.95(10)$ & 189 & $19.58(37)$ \\
\hline $\begin{array}{l}\text { Jan., } \\
2016\end{array}$ & 138 & $3.62(5)$ & 168 & $6.55(11)$ & 126 & $7.14(9)$ & 158 & $4.43(7)$ & 176 & $11.36(2)$ \\
\hline Feb. & 151 & $1.32(2)$ & 180 & $5.56(10)$ & 133 & $2.26(3)$ & 173 & $2.31(4)$ & 199 & $2.51(5)$ \\
\hline Mar. & 0 & $0.00(0)$ & 0 & $0.00(0)$ & 0 & $0.00(0)$ & 0 & $0.00(0)$ & 0 & $0.00(0)$ \\
\hline Apr. & 2 & $0.00(0)$ & 1 & $0.00(0)$ & 0 & $0.00(0)$ & 3 & $0.00(0)$ & 14 & $7.14(1)$ \\
\hline May & 172 & $\begin{array}{c}30.81 \\
(53)\end{array}$ & 254 & $\begin{array}{c}37.40 \\
(95)\end{array}$ & 135 & $\begin{array}{c}17.03 \\
(23)\end{array}$ & 191 & $20.42(39)$ & 301 & $57.80(174)$ \\
\hline June & 143 & $\begin{array}{c}25.17 \\
(36) \\
\end{array}$ & 188 & $\begin{array}{c}20.74 \\
(39) \\
\end{array}$ & 105 & $\begin{array}{c}16.19 \\
(17) \\
\end{array}$ & 175 & $29.71(52)$ & 193 & $52.85(102)$ \\
\hline $\begin{array}{l}\text { Mean } \\
\pm S D\end{array}$ & $\begin{array}{c}128.50 \\
\pm \\
18.32\end{array}$ & $\begin{array}{c}\% \\
\text { mines } \\
12.27 \% \\
\text { Pest } \\
\text { larvae } \\
15.83 \pm 5 . \\
28\end{array}$ & $\begin{array}{c}158.92 \\
\pm \\
22.76\end{array}$ & $\begin{array}{c}\% \text { mines } \\
16.57 \% \\
\\
\text { Pest } \\
\text { larvae } \\
26.33 \pm 8 . \\
71\end{array}$ & $\begin{array}{c}104.33 \\
\pm \\
14.44\end{array}$ & $\begin{array}{c}\% \text { mines } \\
10.94 \% \\
\\
\text { Pest } \\
\text { larvae } \\
11.42 \pm 2 . \\
99\end{array}$ & $\begin{array}{c}146.67 \\
\pm \\
20.40\end{array}$ & $\begin{array}{c}\% \text { mines } \\
13.30 \% \\
\\
\text { Pest } \\
\text { larvae } \\
19.52 \pm 7.2 \\
5\end{array}$ & $\begin{array}{c}174.08 \\
\pm \\
24.51\end{array}$ & $\begin{array}{c}\% \text { mines } \\
20.68 \% \\
\\
\text { Pest } \\
\text { larvae } \\
36.00 \pm 15.3 \\
4\end{array}$ \\
\hline
\end{tabular}

* Total no. of pest larvae. 
From Table (3), it was found that, the highest monthly mean percentages of $P$. citrella mines that contain alive pest larvae were; 35.15 \& 32.69\% during November, 2015 and May, 2016, respectively. The highest monthly recorded mean numbers of pest larvae were; $57.80 \& 76.20 \%$, in November, 2015 and May, 2016, respectively (where, the temperature degrees were higher in these two months). In general, the obtained results showed that, the highest infestation level by $P$. citrella may be due to two factors; the increase of the temperature and the occurrence of newly fresh leaves in spring months and November. So, when planning Integrated Pest Management (IPM) programs against $P$. citrella, these programs must be strongly concentrated during these months. On contrast, Singh and Azam (1986) revealed that, $P$. citrella is active throughout the year especially of fresh growth occurrence. Similarly to our results, Penã et al (1996) reported that, the increase in the population of $P$. citrella in spring could be more related to the increase in temperature (i.e., favorable temperatures for miner development) than to the presence of new shoots. Also, Chhetry et al (2012) demonstrated that, the peaks of $P$. citrella infestations were coincided with the availability of new flush and the percentages of infestation were significantly and positively correlated with the maximum and minimum temperatures and average rainfall.

Statistical analysis of the obtained data showed positive relationships between the South direction of the orange tree and the three other directions (East, West \& North) and also the middle of the tree, in case of comparing the total numbers of $P$. citrella larvae and the total numbers of pest mines (where, the r-values were; 0.929, 0.892, 0.660 and 0.660 , respectively (Table, 4$)$ ).

However, positive relationships were found between the means of temperature and the total numbers of damaged leaves by $P$. citrella, the total numbers of pest mines and the total numbers of pest larvae (where, the r-values were; $0.080,0.122$ and 0.132 , respectively). Also, positive relationship was found between the means of relative humidity with the total numbers of pest mines (where, the $r$-values was 0.316 ). A positive relationship was found between the means of wind speed and the total numbers of pest larvae (where, the r-value was 0.023$)$, (Table, 5).

\section{III- The predatory species observed in orange orchard}

Data in Figs. (1\&2) summarized the field observations on the common predatory species surveyed in the orange orchard. These predatory insect species were belonging to 4 orders and 4 families including the following, Chrysoperla carnea (Steph.) (Neuroptera: Chrysopidae) Coccinella undecimpunctata L., and Scymnus sp. (Coleoptera: Coccinellidae), Orius sp. (Hemiptera: Anthocoridae), Metasyrphus sp. (Diptera: Syrphidae). Moreover, true spiders (Araneae) and predatory mites (unidentified species), were also recorded. Results indicated that, the sequence of predatory species occurrence was descending as follows: true spiders (114 individuals) $>$ the predatory mites (53) > C. undecimpunctata $(28)>C$. carnea $(20)>$ Orius sp. (7) > Metasyrphus sp. (5) > Scymnus sp. (4).

In addition, the obtained results also indicated that the animal predatory species (true spiders \& predatory mites), were more abundant than all other recorded insect predatory species in the orange orchard. The highest total number of the insect predatory species was during April, 2016 (35 individuals), while, that of the animal ones was during July, 2015 (47 individuals). The highest total numbers of all observed common predatory species were during July, 2015, followed by April, 2016 (as shown in Fig., 1).

As illustrated in Fig. (2), the sequence of the predatory species occurrence in the four directions and the middle of the orange tree was descending as follows; the North direction (70 individuals) $>$ the South direction (54) $>$ the East direction $(50)>$ the West direction $(37)>$ the middle of the orange trees (20).

Many of the previously recorded predatory species were shown to be related with the leafminer $P$. citrella such as: spiders (Hoy \& Nguyen, 1997; Amalin et al 2002 and ElekÇioğlu, 2013); C. carnea (Ateyyat \& Mustafa, 2000; Amalin et al 2002 and ElekÇioğlu, 2013) and mired bugs (Amalin et al 2002). Similar to the obtained results, Urbaneja et al (2004); Yingfang et al (2012) and ElekÇioğlu, (2013) stated that, among the mortality factors, spiders were the most important predators of $P$. citrella. The last author demonstrated that, lacewing and spiders puncture 
Table 3. Monthly damaged of orange leaves, caused by $P$. citrella, during July, 2015 until June, 2016, at Qaluobiya Governorate.

\begin{tabular}{|l|c|c|c|c|c|}
\hline \multirow{2}{*}{ Months } & \multicolumn{5}{|c|}{ Mean / 1000 monthly leaves sample } \\
\cline { 2 - 6 } & $\begin{array}{c}\text { Total no. of } \\
\text { damaged } \\
\text { leaves }\end{array}$ & $\begin{array}{c}\text { \% damage } \\
\text { of } \\
\text { leaves }\end{array}$ & $\begin{array}{c}\text { Total no. } \\
\text { of } \\
\text { pest mines }\end{array}$ & $\begin{array}{c}\text { Total no. } \\
\text { of } \\
\text { pest larvae }\end{array}$ & $\begin{array}{c}\text { \% mines } \\
\text { containing alive } \\
\text { pest larvae }\end{array}$ \\
\hline July, 2015 & 125.00 & 62.50 & 179.00 & 19.00 & 10.53 \\
Aug. & 115.40 & 59.50 & 143.80 & 5.00 & 3.41 \\
Sept. & 145.00 & 72.40 & 207.00 & 6.80 & 3.12 \\
Oct. & 141.80 & 70.90 & 157.00 & 11.20 & 7.31 \\
Nov. & 154.20 & 77.10 & 161.40 & 57.80 & 35.15 \\
Dec. & 145.60 & 72.80 & 166.00 & 24.20 & 14.33 \\
Jan., 2016 & 140.00 & 69.90 & 153.20 & 6.80 & 6.62 \\
Feb. & 157.00 & 78.50 & 167.20 & 4.80 & 2.79 \\
Mar. & 0.00 & 0.00 & 0.00 & 0.00 & 0.00 \\
Apr. & 3.40 & 1.70 & 4.00 & 0.20 & 1.43 \\
May & 155.60 & 77.80 & 210.60 & 76.20 & 32.69 \\
June & 126.40 & 63.30 & 160.80 & 49.20 & 28.93 \\
\hline Mean \pm SD & $117.45 \pm 16.04$ & $58.87 \%$ & $142.50 \pm 19.81$ & $21.82 \pm 7.37$ & $12.19 \%$ \\
\hline
\end{tabular}

Table 4. Correlations (r-values) in case of the total numbers of $P$. citrella larvae, the total numbers of pest mines and the comparison (t-test) between the means of the total numbers of pest mines, for the South direction and the other three directions \& the middle of the orange tree, in Qaluobiya Governorate

\begin{tabular}{|c|c|c|c|}
\hline \multirow{2}{*}{ Tested factors } & \multicolumn{2}{|c|}{ Correlations (r-value) } & t-values \\
\cline { 2 - 4 } & $\begin{array}{c}\text { Total no. of pest } \\
\text { larvae }\end{array}$ & $\begin{array}{c}\text { Total no. of pest } \\
\text { mines }\end{array}$ & $\begin{array}{c}\text { Comparison between means } \\
\text { of total no. of pest mines } \\
\text { (significance) }\end{array}$ \\
\hline South $\times$ East & $0.929^{* *}$ & $0.944^{* *}$ & 0.025 (t-value $=984.32)$ \\
South $\times$ West & $0.892^{* *}$ & $0.990^{* *}$ & 0.060 (t-value $=168.73)$ \\
South $\times$ Middle & $0.660^{*}$ & $0.934^{* *}$ & 0.136 (t-value $=32.48)$ \\
South $\times$ North & $0.660^{*}$ & $0.951^{* *}$ & 0.030 (t-value $=686.43)$ \\
\hline
\end{tabular}

${ }^{*}=$ Correlation is significant at the level 0.01 .

Table 5. Correlations ( $r$-values) and regression equations, in case of the total numbers of $P$. citrella damaged leaves, the total numbers of pest mines and the total numbers of pest larvae with the weather factors, in the orange orchards, in Qaluobiya Governorate

\begin{tabular}{|c|c|c|c|c|c|c|}
\hline \multirow{3}{*}{ Tested factors } & \multicolumn{3}{|c|}{ Correlations } & \multicolumn{3}{|c|}{ Regression (b) } \\
\hline & \multirow[t]{2}{*}{ Temp. $\left({ }^{\circ} \mathrm{c}\right)$} & \multirow[t]{2}{*}{ R.H.\% } & \multirow{2}{*}{$\begin{array}{l}\text { Wind } \\
(\mathrm{km} / \mathrm{h})\end{array}$} & $\begin{array}{c}\text { Temp. } \\
\left.\text { ( }{ }^{\circ} \mathrm{C}\right)\end{array}$ & R.H.\% & Wind $(\mathrm{km} / \mathrm{h})$ \\
\hline & & & & r-values & r-values & r-values \\
\hline Total no. of damaged leaves & $0.080^{*}$ & 0.498 & 0.377 & 0.03 & 0.50 & 0.38 \\
\hline Total no. of pest mines & $0.122^{*}$ & $0.316^{*}$ & 0.355 & 0.12 & 0.32 & 0.35 \\
\hline Total no. of pest larvae & $0.132^{*}$ & 0.045 & $0.023^{*}$ & 0.13 & 0.04 & 0.03 \\
\hline
\end{tabular}



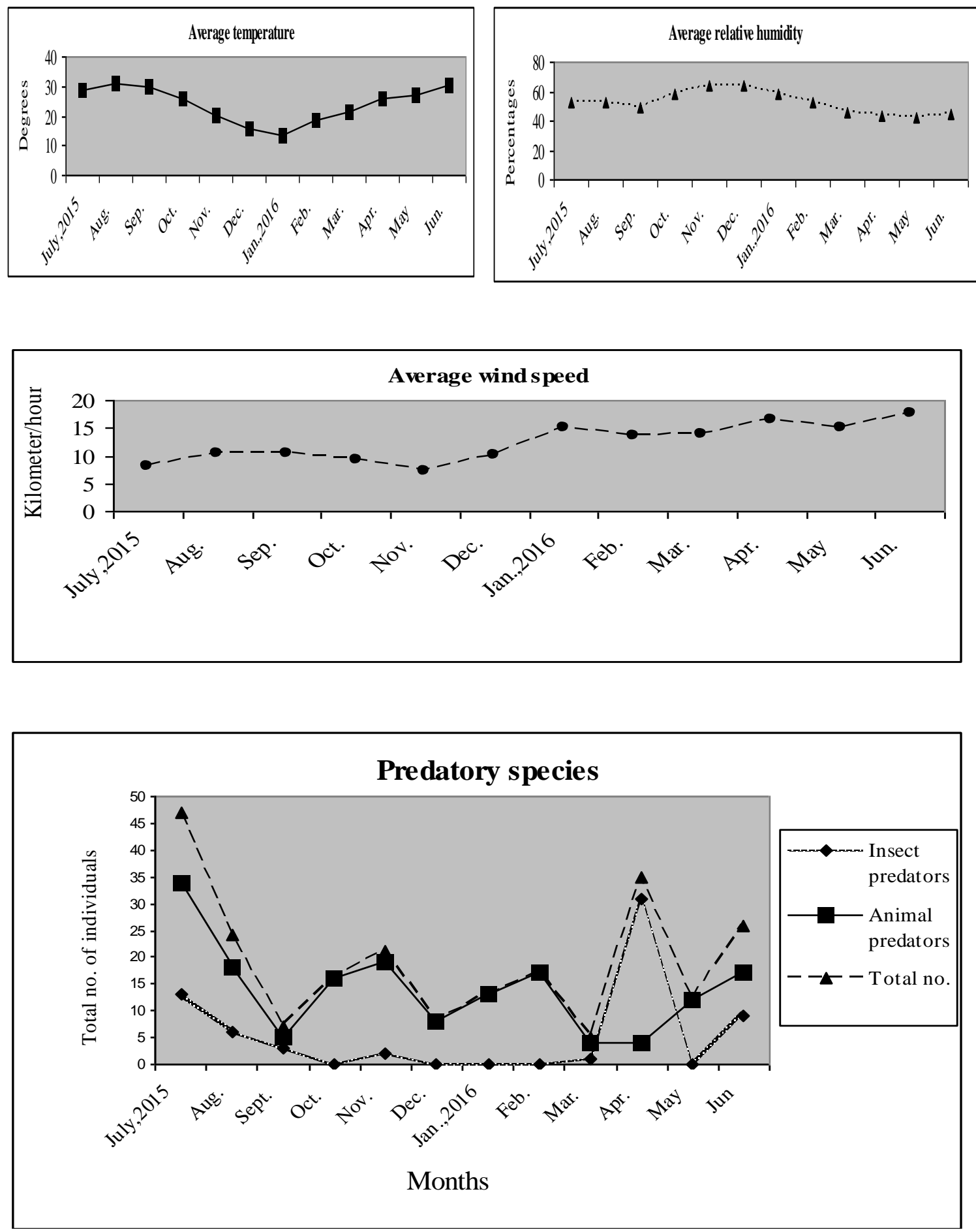

Fig. 1. Total numbers of predatory species recorded in orange orchard, during the period lasted from the beginning of July, 2015 until the end of June, 2016 (in relation to weather factors), in Qaluobiya Governorate 

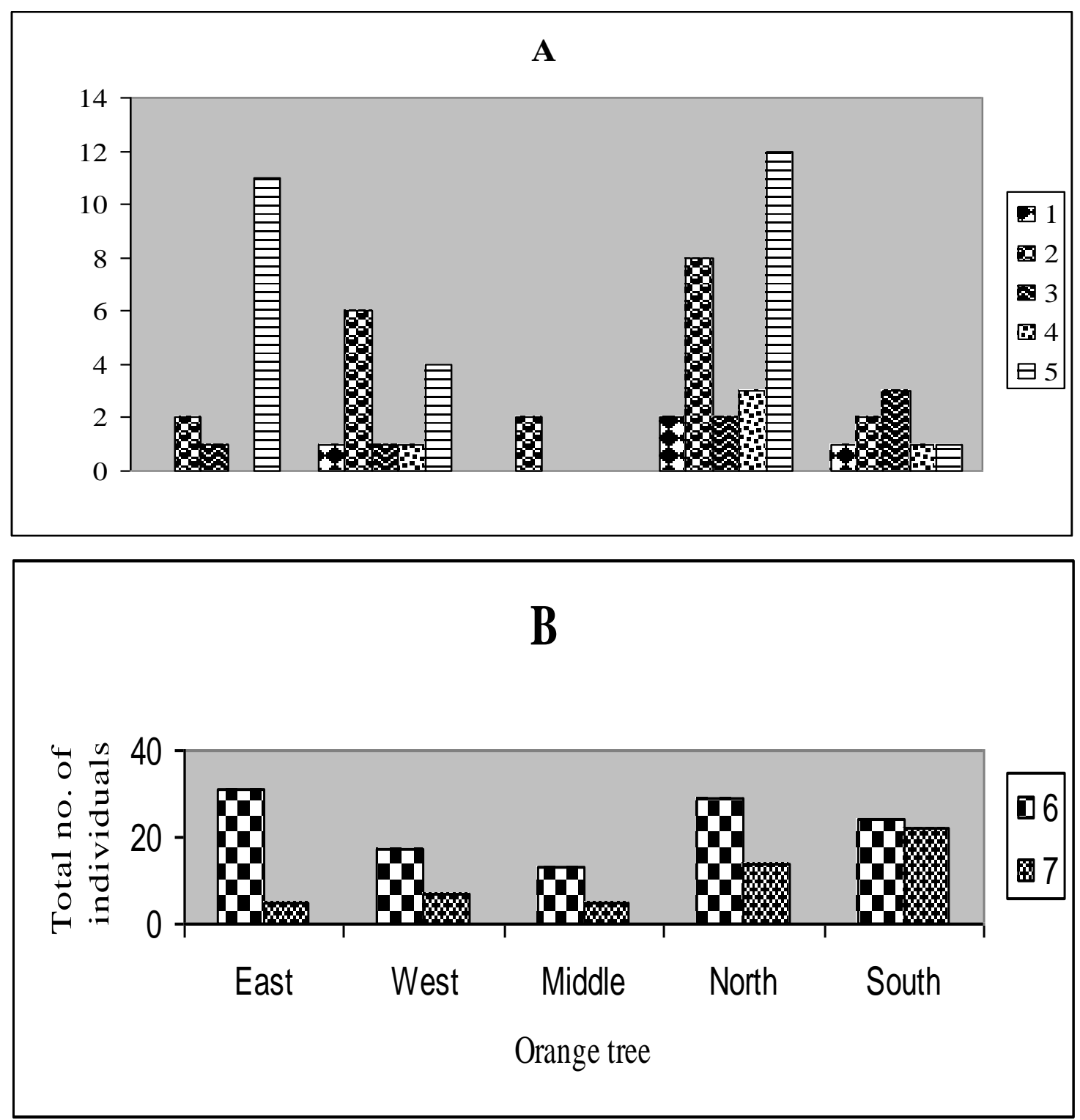

Fig. 2. Total numbers of predatory species recorded in the four directions and the middle of orange trees during the period lasted from the beginning of July, 2015 until the end of June, 2016, in Qaluobiya Governorate

\section{A (insect predators)}

1 Scymnus sp. (adults \& nymphs)

$4 \quad$ Metasyrphus sp. (larvae)

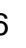

True spiders (Araneae) $\begin{array}{lll}\text { C. carnea (larvae) } & 3 & \text { Orius sp. (adults \& larvae }\end{array}$

C. undecimpunctata (adults \& larvae)

B (animal predators)

$7 \quad$ Predatory mites (an unidentified 
the mine of $P$. citrella for predation (representing the method of predation). He added that, predation was the main mortality factor of the first larval instars of $P$. citrella and therefore predators are effective in the biological control of the pest. However, Huang et al. (1989) concluded that, the abiotic factors and predation may be two major causes of $P$. citrella mortality, during the first and second stages. While, Ateyyat \& Mustafa (2000) showed that, $C$. carnea predation on $P$. citrella was higher in spring than other months. They concluded that, the predation by spiders was higher in autumn than any other observation periods. Finally, Urbaneja et al (2004) revealed that, predators responded to changes in flushing, and this was attributed to continuous availability of preferential prey feeding on tender flushes.

In conclusion, the obtained results in this study throw the light on the following important points:

1- The South direction of the orange tree had the highest percentages of leaves damage by the citrus leafminer, $P$. citrella. So it is recommended to begin the Integrated Pest Management (IPM) programs against the pest firstly in this direction and also at the suitable time of infestation.

2- The warmer months that have the highest temperature degrees and the newly fresh orange leaves, had the highest percentages of infestation by the pest.

3- The importance of the natural role of the common predatory species recorded in the orange orchard is obviously shown and must be encouraged and developed. Of these predatory species recorded in this study, true spiders were the most common ones.

4- Many of the recorded predatory species such as: C. carnea, Scymnus sp., C. undecimpunctata and Orius sp., can be mass reared in the laboratory and released in the orange orchards against $P$. citrella or other related pests with these predators (such as the citrus aphids and mealybugs). This approach is believed to be practical and safe for use with the frame work of IPM programs in Egypt.

\section{REFERENCES}

Abd El-Aziz, S.E. 1996. Relative susceptibility of some citrus species to the infestation of the citrus leafminer, Phyllocnistis citrella Staint in Egypt. (Lepidoptera : Gracillariidae). Bull. Ent. Soc. Egypt, 74, 90-99.
Abo Abdalla, L.M.Z. 2015. Seasonal abundance of the citrus leafminer Phyllocnistis citrella Stainton (Lepidoptera : Gracillariidae) and its parasitoids in Alexandria, Egypt. Egypt. J. Biol. Pest Control, 25(3), 597- 602.

Amalin, D.M., Penã, J.E., Ducan, R.E., Browning, H.W. and Csorley, R.M. 2002. Natural mortality factors acting on citrus leafminer, Phyllocnistis citrella in lime orchards in South Florida. Biocontrol. 47(3), 327-347.

Ateyyat, M. and Mustafa, T. 2000. Mortality factors of citrus leafminer, Phyllocnistis citrella (Stainton) (Lepidoptera : Gracillariidae) on lemon in Central Jordan Valley. Phytophaga, 10, 35- 42.

Beattie, G.A.C. and Smith, D. 1993. Citrus leafminer. $\mathrm{Ag}$ fact H2. AE. 4. $2^{\text {nd }}$ ed. New South Wales Agriculture and Fisheries, Orange, Australia, 6p.

Charles, A.P., Burton, M.S., Pelosi, R., Ritenour, M.A. and Bullock, R.C. 2007. Seasonal abundance and insecticidal control of citrus leafminer in a citrus orchard. Hortscience, 42(7), 1636-1638.

Chhetry, M., Gupta, R., Jara, J.S. and Pathania, P.C. 2012. Seasonal abundance of citrus leafminer, Phyllocnistis citrella Stainton (Lepidoptera : Gracillariidae) from Jammu and Kashmir. J. Insect, Sci. 25(2), 144-149.

Diez, P.A., Penã, J.E. and Fidalgo, P. 2006. Population dynamics of citrus leafminer, Phyllocnistis citrella Stainton (Lepidoptera : Gracillariidae) and its parasitoids in Tafi Viejo Tucuman, Argentina. Florida Entomol, 89(3), 328-335.

Elekçioğlu, N.Z. 2013. Determination of the natural mortality factors of citrus leafminer, Phyllocnistis citrella Stainton (Lepidoptera : Gracillariidae) in Adana Provine, Turkey. Tur. Entomol. Derg, 37(1), 21-30.

Garcia-Mari, F., Granad, C., Zaragoza, S. and Agusti, M. 2002. Impact of citrus leafminer, Phyllocnistis citrella (Lepidoptera : Gracillariidae) on leaf area development and yield of mature citrus trees in the Mediterranean area J. Econ. Entomol, 95, 966-974.

Graham, J.H., Gottwald, T.R., Cubero, J. and Achor, D.S. 2004. Xanthomonas axonopodis pv. citri factors affecting successful eradication of citrus canker. Molecular Plant Pathology, 5, 1-15. 
Hoy, M.A. and Nguyen, R. 1997. Classical biological of the citrus leafminer Phyllocnistis citrella Stainton (Lepidoptera : Gracillariidae): theory, practice, art and science. Tropical Lepidoptera. 8, 1-19.

Huang, M.L., Lu, Y.S., Qiu, Z.S., Zhou, Q.M., Men, Y.J. and Lin, S.G. 1989. Life history of Phyllocnistis citrella Stainton and its occurrence. Acta Phytophylactica Sinica, 16, 159162.

Khalil, A.A., Wazzan, R.A. and Gobran, Y.N. 2001. Some aspects of leaves growth, leaf characters and some methods of irrigation in relation to CLM infestation on mature navel orange trees. Bull. Fac. Agric., Cairo Univ., 52(2), 259-278.

Knapp, J., Penã, J., Stansly, P., Heppner, J. and Yang, Y. 1994. The citrus leafminer, Phyllocnistis citrella, a new pest of citrus in Florida. Florida Cooperative Extension Service Ins. Food \& Agric. Sci. Univ. of Florida, pp. 1-4.

Michaud, J.P. and Grant, A.K. 2003. IPM compatibility of foliar insecticides for citrus insects from four orders. J. Insect. Sci., 3, 1-8.

Penã, J.E. and Duncan, R. 1993. Control of citrus leafminer in South Florida. Proc. Fla. State Hortic. Soc., 106, 47-51.

Penã, J.E., Duncan, R. and Browning, H. 1996. Seasonal abundance of Phyllocnistis citrella (Lepidoptera : Gracillariidae) and its parasitoids in South Florida Citrus. Environ. Entomol., 25(3), 698-702.

Penã, J.E., Hunsberger, A. and Schaffer, B. 2000. Citrus leafminer (Lepidoptera : Gracillariidae) density: effect on yield of "Tahiti" line. J. Econ. Entomolo., 93, 374- 379.
Rosell, G., Quero, C., Cou, J. and Guerrero, A. 2008. Bioregional insecticides in pest management. J. Pesticide Sci., 33(2), 103-121.

Sanghyeob, L., II-Kwon, K., Kyu-Young, P., Chung-Won, C., Bqng and B-Kyu 2015. Preliminary survey of indigenous parasites associated with Phyllocnistis citrella Stainton (Lepidoptera : Gracillariidae) in Jeju, Korea. Journal of Asia-Pacific Biodiversity, 8, 371-374.

Shaban, A.M. and Ohbayash, N. 2006. Toxicity of insecticides to the citrus leafminer, Phyllocnistis citrella and its parasitoids hrysocharis penthenus and Sympiesis striatipes (Hymenoptera: Eulophidae). Appl. Entomol. Zool., 41(1), 3339.

Singh, Tvk and Azam, K.M. 1986. Seasonal occurrence, population dynamics and chemical control of citrus leafminer, Phyllocnistis citrella Stainton in Andhra Pradesh. Indian J. Entomol., 48(1), 38-42.

Snedecor, G.W. and Cochran, W.G. 1980. Statistical Methods. The lowa State Univ. Press, Ames. lowa. USA.

Urbaneja, H., Muňoz, A., Garrido, A. and Jacas, J.A. 2004. Which roles do lacewings and ants play predators of the citrus leafminer in Spain?. Spainsh Journal of Agricultural Research, 2(3), 377-384.

Yingfang, X., Henry, Y. and Fadamiro 2012. Exclusion experiments reveal relative contributions of natural enemies to mortality of citrus leafminer, Phyllocnistis citrella (Lepidoptera : Gracillariidae) in Alabama Satsuma orchards. Biol. Cont., 54, 189-196. 